\title{
HAEMOGLOBIN E TRAIT: A FREQUENTLY INCRIMINATED INNOCENT TRAIT
}

\author{
BISWAS AR ${ }^{1}$, TASNEEM ARA T ${ }^{2}$
}

\begin{abstract}
:
Background: Haemoglobin ( $\mathrm{Hb}$ ) level in $\mathrm{Hb} \mathrm{E}$ trait or heterozygous $\mathrm{Hb} \mathrm{E}$ usually does not go bellow reference level, so does not causes any significant anaemia. However, many medical practitioner conclude $\mathrm{Hb} \mathrm{E}$ trait as a cause of anaemia when they find $\mathrm{Hb} \mathrm{E}$ trait in the course of evaluation.
\end{abstract}

Objective:The objective of this case series is to find out whether $\mathrm{Hb}$ E trait can be a cause of significant anaemia or not.

Methods: A series of cases of $\mathrm{Hb}$ E trait with significant anaemia was systematically evaluated to find out the real cause of anaemia and treated accordingly and followed up to find out whether $\mathrm{Hb} \mathrm{E}$ trait itself can be a cause of anaemia at all.

Result: Out of 13 anaemic patients presented with the diagnosis of $\mathrm{Hb} E$ trait, 1 was not $\mathrm{Hb}$ $E$ tarit at all but $\mathrm{Hb}$ E/ â thalassaemia. Out of 12 actual $\mathrm{Hb} E$ trait, 1 expired within treatment for acute lymphoblastic leukaemia. Correctable cause of anaemia was found in 10 out of remaining 11 cases and 1 case had very high CRP and didn't comply with further investigation. Anaemia was corrected with treatment in 9 cases and partially corrected in 1 case who was not compliant to regular treatment.

Conclusion: $\mathrm{Hb} \mathrm{E}$ trait is not a cause of significant anaemia and a probable incidental finding in anaemic patient undergoing $\mathrm{Hb}$ electrophoresis, especially in areas where $\mathrm{Hb} \mathrm{E}$ is quite common like Bangladesh.

Key Words: Anaemia, Haemoglobin E, Thalassaemia.

J Dhaka Med Coll. 2017; 26(1) : 32-35

\section{Introduction:}

Haemoglobin $\mathrm{E}$ is a $\beta$ globin variant haemoglobin, most common in southeast Asia and adjoining regions like Bangladesh ${ }^{1-3}$. It is a variant haemoglobin with mild â thalassaemic phenotype. In homozygous form it is like thalassaemia minor both clinically and haematologically, that is mildly anaemic or not anaemic at all with slightly reduced haemoglobin level, markedly reduced mean corpuscular volume (MCV) and mean corpuscular haemoglobin ( $\mathrm{MCH})$, normal mean corpuscular haemoglobin concentration $(\mathrm{MCHC})$ and raised or upper normal number of red blood cells (RBCs). However in heterozygous form it is completely normal clinically and haemogram is also within normal limit except mild microcytosis and $\mathrm{Hb}$ level is only insignificantly lower than reference in some cases. Due to it's â thalassaemic phenotype, double heterozygous haemoglobin $\mathrm{E} / \beta$ thalassaemia is symptomatic and present most commonly as thalassaemia intermedia followed by thalassaemia major and a small fraction may behave like thalassaemia minor as well. ${ }^{1,4}$

To perform haemoglobin electrophoresis as part of anaemia evaluation is a common practice among physicians of Bangladesh. As haemoglobin $\mathrm{E}$ is a prevalent haemoglobin variant found in Bangladeshi population a significant number of haemoglobin $\mathrm{E}$ trait is detected incidentally in the course of such evaluation process. ${ }^{1}$. Due to limited information to Bangladeshi physicians about the clinical phenotype of haemoglobin $\mathrm{E}$ trait, many a times they diagnose this hereditary haemoglobin defect as cause of anaemia of the patient under evaluation, which result in masking of actual cause of anaemia. To alleviate this misconception these authors attempted to explore and correct the cause of anaemia in a series of cases of haemoglobin E trait with significant anaemia.

Dr. Akhil Ranjon Biswas, Associate Professor, BMT, Dept. of Hematology, Dhaka Medical College Dr. Tasneem Ara, Associate Professor, Dept. of Haematology, Dhaka Medical College

Correspondence: Dr. Akhil Ranjon Biswas, Associate Professor, BMT, Department of Haematology, Dhaka Medical College, Dhaka, E-mail: akhil.biswas@yahoo.com, Cell No. +8801712290706 


\section{Method:}

It was an observation of series of cases with variable intervention as required (according to cause of anaemia found). A total of 13 cases of already diagnosed haemoglobin $\mathrm{E}$ trait having significant anaemia (haemoglobin d" $10 \mathrm{gm} /$ dl) were evaluated to explore the cause of anaemia. Out of them 12 were diagnosed as haemoglobin $\mathrm{E}$ trait earlier in the course of investigation for anaemia. Another anaemic lady was mother of a child with homozygous haemoglobin $\mathrm{E}$, so was an obligate heterozygous for haemoglobin E. Past treatment for their conditions were also explored from history. After exploration of cause of anaemia, patients were treated accordingly and result of treatment was evaluated finally. Result of treatment was evaluated in two stages. Early evaluation was done by reticulocyte response following haematinics, where appropriate. Late evaluation with complete blood count was done at time when full recovery was expected.

\section{Result:}

When fully evaluated for the cause of anaemia iron deficiency was detected in 8 cases, out of those eight one had hypothyroidism as well, however hypothyroidism was found in 1 more case. Chronic inflammation was found in one of iron deficient cases. One has megaloblastic anaemia due to vit-B12 deficiency, 1 has chronic disease, 1 was diagnosed as acute lymphoblastic leukaemia and 1was diagnosed as haemoglobin E/â thalassaemia so his earlier diagnosis of haemoglobin $\mathrm{E}$ trait was not correct. Out of all 13 cases 10 (case no. 1to 10) were treated earlier and 3 (case no. 11 to 13) were presented to one of the authors for first time for evaluation of anaemia. Out of 10 cases treated earlier, haemoglobin $\mathrm{E}$ trait was designated as the cause of their anaemia in 9 cases and iron deficiency was designated as cause of anaemia in 1 case.

Regarding treatment of those 10 cases treated earlier, 7 were transfused blood, 1 was treated symptomatically, 1 was referred to Haematology and 1 was treated with iron preparation but inadequately so anaemia recurred. All 10 cases were advised to avoid iron rich food in a long run with the fear of 'iron loading'. Red cell indices along with other relevant findings of all 13 cases during their first evaluation by the authors are given in table- 1 .

All the cases have been offered treatment, appropriate for the cause of anaemia identified. Those 8 cases found to have iron deficiency was given iron replacement either oral or parenteral. Case number 9, who had chronic inflammation along with iron deficiency, was incompliant to intravenous as well as oral iron. Case number 13 received iron replacement properly, however continued to take thyroid hormone replacement irregularly.

Case 4 was treated with titrated dose of thyroxine and followed till 2 month after achieving euthyroid status. Case number 10 was treated with intramuscular hydroxocobalamin $1 \mathrm{mg}$ twice weekly with total 8 doses.

Case 3 was actually a case of haemoglobin E/â thalassaemia and was behaving as thalassaemia intermedia. He was given hydroxyurea $500 \mathrm{mg}$ daily and folic acid supplementation $5 \mathrm{mg}$ daily indefinitely. Transfusion as needed was planned and long term management of thalassaemia intermedia was explained to him. Case 5 was given induction chemotherapy for acute lymphoblastic leukaemia, who succumbed of therapy related complication from myelosuppression. Only the case number 2 lost from treatment and follow up process.

Out of 13 cases, 12 was actually haemoglobin $\mathrm{E}$ trait and remaining one was actually a case of haemoglobin E/â thalassaemia wrongly diagnosed as haemoglobin $\mathrm{E}$ trait earlier. Out of those 12 cases one expired during the treatment of acute lymphoblastic leukaemia. Out of remaining 11 cases correctable cause/ causes of anaemia was detected in 10 cases and in only one case definite cause was not explored, though evidence of inflammation, high C-reactive protein (CRP), was found. Correction of anaemia or laboratory evidence of response to corrective measure were found in 9 out of 10 cases (Table- II), remaining one was non compliant to treatment. 
Table I

Pre treatment clinical \& laboratory profile of all anaemic cases with $\mathrm{Hb}$ E trait.

\begin{tabular}{|c|c|c|c|c|c|c|c|c|c|c|}
\hline $\begin{array}{l}\text { Case } \\
\text { No. }\end{array}$ & $\begin{array}{l}\text { Age } \\
\text { year }\end{array}$ & $\begin{array}{l}\mathrm{Se} \\
\mathrm{x}\end{array}$ & $\begin{array}{l}\text { Haemog } \\
\text { lobin } \\
\text { (gm/dl) }\end{array}$ & $\begin{array}{l}\mathrm{RBC} \\
\left(\times 10^{12}\right. \\
\mathrm{L})\end{array}$ & $\begin{array}{c}\text { MCV } \\
(\mathrm{fl})\end{array}$ & $\begin{array}{l}\mathrm{MCH} \\
(\mathrm{pg})\end{array}$ & $\begin{array}{l}\mathrm{MCHC} \\
(\mathrm{gm} / \mathrm{dl})\end{array}$ & $\begin{array}{l}\text { RDW- } \\
\text { CV } \\
\%\end{array}$ & Other Important Features & $\begin{array}{l}\text { Proposed Actual } \\
\text { Cause of Anemia }\end{array}$ \\
\hline 1 & 29 & $\mathrm{~F}$ & 6.6 & 5.04 & 46.8 & 13.1 & 28.0 & 24.1 & $\begin{array}{l}\text { Serum Ferritin- } 2.7 \mathrm{ng} / \mathrm{ml} \text {, Transferrin Saturation- } \\
3.3 \% \text {. }\end{array}$ & Iron Deficiency \\
\hline 2 & 18 & $\mathrm{~F}$ & 9.9 & 3.86 & 77.7 & 25.6 & 33.0 & 13.2 & CRP- $13.5 \mathrm{mg} / \mathrm{L}$, Neutrophil- $14.4 \times 10^{9} / \mathrm{L}$ & Chronic inflamation \\
\hline 3 & 26 & M & 8.3 & 5.29 & 45.7 & 15.7 & 34.3 & 20.7 & $\begin{array}{l}\text { Moderate splenomegaly. PBF- anisopoikilocytosis, } \\
\text { target cells (plenty), tear drop cells, schistocytes and } \\
\text { occasional nucleated RBCs. Hb Electrophoresis- } \mathrm{Hb} \\
\text { E/Beta thalassemia }\end{array}$ & $\begin{array}{l}\mathrm{Hb} \text { E/Beta } \\
\text { thalassaemia }\end{array}$ \\
\hline 4 & 46 & $\mathrm{~F}$ & 8.9 & 3.21 & 84.6 & 27.7 & 32.8 & 14.4 & Sluggish ankle jerk. TSH >75 mlU/L, $\mathrm{T}_{4} 28 \mathrm{nmol} / \mathrm{L}$. & Hypothyroidism \\
\hline 5 & 17 & $M$ & 7.7 & 2.9 & 80.0 & 26.5 & 33.1 & 18.0 & $\begin{array}{l}\text { PBF and Bone Marrow: Acute Lymphoblastic } \\
\text { Leukaemia }\end{array}$ & Acute leukemia \\
\hline 6 & 19 & $M$ & 6.6 & 3.13 & 74.4 & 21.1 & 28.3 & 26.3 & $\begin{array}{l}\text { Hepatosplenomegaly, Koilonychea, Ferritin- } 9.54 \\
\text { ng/ml, Transferrin Saturation- } 8.5 \% \text {, Stool OBT- } \\
\text { positive. }\end{array}$ & Iron deficiency \\
\hline 7 & 30 & $\mathrm{~F}$ & 4.4 & 2.98 & 54.7 & 14.8 & 27.0 & 23.0 & $\begin{array}{l}\text { Splenomegaly, Engorgement of veins of anterior } \\
\text { abdominal wall, Grade II oesophageal varices, } \\
\text { Serum Ferritin- } 11.02 \mathrm{ng} / \mathrm{ml} \text {. }\end{array}$ & Iron deficiency \\
\hline 8 & 16 & $\mathrm{~F}$ & 8.4 & 5.20 & 59.6 & 16.2 & 27.1 & 25.3 & Serum Ferritin- $3.54 \mathrm{ng} / \mathrm{ml}$. & Iron deficiency \\
\hline 9 & 35 & $\mathrm{~F}$ & 8.1 & 4.4 & 60.0 & 18.0 & 30.0 & & $\begin{array}{l}\text { Ferritin- } 2.85 \mathrm{ng} / \mathrm{ml} \text {, Transferrin Saturation- } 9 \% \text {, } \\
\text { ESR- } 88 \mathrm{~mm} \text { in } 1^{\mathrm{st}} \text { hour, } \mathrm{Hb} \mathrm{A} \mathrm{A}_{1 \mathrm{c}}, 9.12 \% \text {. }\end{array}$ & $\begin{array}{l}\text { Iron deficiency with } \\
\text { uncontrolled } \\
\text { diabetes }\end{array}$ \\
\hline 10 & 35 & M & 6.8 & 1.8 & 110 & 37.0 & 33.6 & & $\begin{array}{l}\text { Strict vegetarian for } 12 \text { years; Serum Vit-B12, } 60.0 \\
\mathrm{pgm} / \mathrm{ml} \text {. }\end{array}$ & Vit-B12 deficiency \\
\hline 11 & 13 & M & 8.7 & 3.91 & 73.7 & 22.3 & 30.2 & 23.0 & Reticulocytosis following iron therapy & Iron deficiency \\
\hline 12 & 24 & $\mathrm{~F}$ & 8.0 & 4.38 & 64.4 & 18.3 & 28.4 & 20.3 & Serum Ferritin- $7.8 \mathrm{ng} / \mathrm{ml}$ & Iron deficiency \\
\hline 13 & 32 & $\mathrm{~F}$ & 8.3 & 4.29 & 62.2 & 19.3 & 31.1 & 18.2 & $\begin{array}{l}\text { Ferritin- } 9.0 \mathrm{ng} / \mathrm{ml} \text {, Transferrin Saturation- } 3.3 \% \text {, } \\
\text { Known hypothyroid with poor control (TSH- } 8 \\
\text { mlU/L). }\end{array}$ & $\begin{array}{l}\text { Iron deficiency with } \\
\text { hypothyroidism }\end{array}$ \\
\hline
\end{tabular}

$(\mathrm{CRP}=\mathrm{C}$-reactive protein, $\mathrm{PBF}=$ peripheral blood film, $\mathrm{Hb}=$ haemoglobin, $\mathrm{RBC}=$ red blood cells, $\mathrm{TSH}=$ thyroid stimulating hormone, OBT= occult blood test)

Table II

Post treatment assessment of cases that were found to have potentially curative causes of anemia

\begin{tabular}{lccccccc}
\hline $\begin{array}{l}\text { Case } \\
\text { No. }\end{array}$ & $\begin{array}{c}\text { Early } \\
\text { Reticulocyte } \\
\text { Response }\end{array}$ & $\begin{array}{c}\text { Haemoglobin } \\
(\mathrm{g} / \mathrm{dl})\end{array}$ & $\begin{array}{c}\mathrm{RBC} \\
\left(\times 10^{12} / \mathrm{L}\right)\end{array}$ & $\begin{array}{c}\mathrm{MCV} \\
(\mathrm{fl})\end{array}$ & $\begin{array}{c}\mathrm{MCH} \\
(\mathrm{pg})\end{array}$ & $\begin{array}{c}\mathrm{MCHC} \\
(\mathrm{g} / \mathrm{dl})\end{array}$ & Comment \\
\hline 1 & $9 \%$ & 13.3 & 5.21 & 74.9 & 25.5 & 34.1 & \\
4 & & 12.4 & 4.9 & 73.8 & 25.3 & 34.3 & $\begin{array}{c}\text { Dimorphic } \\
\text { red cells }\end{array}$ \\
6 & $8.5 \%$ & & & & & & \\
7 & $7 \%$ & 11.4 & 4.4 & 78.0 & 25.9 & 33.2 & \\
8 & & 13.1 & 5.36 & 70.0 & 24.4 & 34.9 & \\
10 & 13.8 & 6.15 & 68.9 & 22.4 & 32.5 & \\
11 & & 12.7 & 5.52 & 69.7 & 23.0 & 33.0 & \\
12 & & 11.2 & 4.86 & 73.0 & 23.0 & 31.5 & \\
13 & & 11.5 & 4.98 & 69.1 & 23.1 & 33.4 & \\
\hline
\end{tabular}




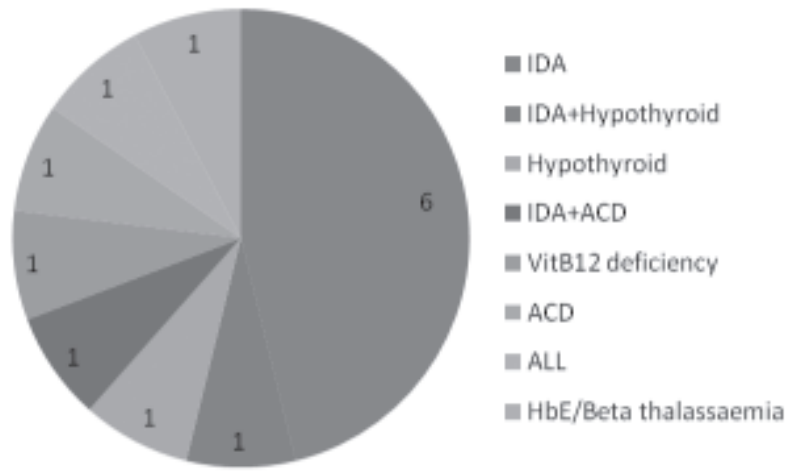

Fig.-1: Distribution of cases according to actual causes of anaemia who were diagnosed as $\mathrm{Hb} \mathrm{E}$ trait. (IDA- iron deficiency anaemia, ACDanaemia of chronic disease, ALL-acute lymphoblastic leukaemia).

\section{Discussion:}

Haemoglobin $\mathrm{E}$ is a variant haemoglobin resulting from nucleotide substitution G'! at codon 26 of â globin gene, changes the amino acid encoded Lysine to Glutamate. Besides amino acid substitution, it creates a new alternative splice site in exon 1 of â globin gene. It makes haemoglobin $\mathrm{E}$ a haemoglobin variant with mild â thalassaemic phenotype. ${ }^{1,5,6}$ Even in homozygous state (haemoglobin E disease) it causes mild anaemia only which is comparable to thalassaemia minor, so quite asymptomatic. In heterozygous state (haemoglobin E trait) it is quite normal clinically except mild reduction of $\mathrm{MCV}$ and $\mathrm{Hb}$ level is only insignificantly lower than reference in some cases. ${ }^{1,5,7,8}$ Finding haemoglobin $\mathrm{E}$ trait in an anaemic patient does not mean that it is the cause of anaemia but an incidental finding only. Systematic evaluation of causes usually always reveals the true causes of anaemia. Actually for the evaluation of anaemia, haemoglobin electrophoresis in $1^{\text {st }}$ line before careful evaluation of patient history and haemogram, may be misleading.

Detection of haemoglobin E heterozygosity in an anaemic patient may hinder rather than help revelation of the cause of anaemia. Out of 10 cases who have been treated earlier, haemoglobin $\mathrm{E}$ trait was designated as the cause of anaemia in 9 cases and iron deficiency as cause of anaemia was designated in one case; indicate a wide misconception about the clinical phenotype of haemoglobin E trait. About 4 to 5\% of Bangladeshi population are heterozygous for haemoglobin E. ${ }^{1-3}$ So, it is very likely to find haemoglobin $\mathrm{E}$ trait incidentally in an anaemic patient. If a physician is not aware of the fact that haemoglobin $\mathrm{E}$ trait is clinically asymptomatic and haematologically almost silent, he is likely to incriminate this innocent condition as the cause of anaemia and miss the actual cause of anaemia.

\section{Conclusion:}

Haemoglobin E trait, like many other variant haemoglobin, is clinically silent condition. It's important to have a clear idea about the genotype-phenotype correlation of any variant haemoglobin (e.g. haemoglobin E) before marking such condition as cause of anaemia. Performing haemoglobin electrophoresis upfront in an anaemic patient without systematic evaluation of anaemia may mislead the diagnosis, especially when genotypephenotype correlation is not kept in mind.

\section{Referances:}

1. Bain BJ. Haemoglobinopathy Diagnosis. $2^{\text {nd }}$ ed. Oxford: Blackwell Publishing; 2006. Chapter 5, Other significant haemoglobinopathies; p. 190233.

2. Khan W A, Banu B, Amin SK, Selimuzzaman M, Rahman M, et al. Prevalence of beta thalassemia trait and $\mathrm{Hb} \mathrm{E}$ trait in Bangladeshi school children and health burden of thalassemia in our population. Dhaka Shishu (child) Health Journal. 2005; 21(1): 1-7

3. Lachant $\mathrm{N}$ A. Hemoglobin E: an emerging hemoglobinopathy in the united states. American Journal of Hematology.1987; 25: 449 - 62

4. Fairbanks VF, Oliveros R, Brandabur JH, Willis RR, Fiester RF. Homozygous hemoglobin E mimics â-thalassemia minor without anemia or hemolysis: Hematologic, functional, and biosynthetic studies of first north American cases. American Journal of Hematology.1980; 8(1): 109-21

5. Borgana-Pignatti C, Galanello R. In: Greer JP, Arber DA, Glader B, List AF, Means Jr RT, Paraskevas F, Rodgers GM, editors. Wintrobe's Clinical Hematology. $13^{\text {th }}$ ed. Philadelphia. Lippincott Williams \& Wilkins, 2014

6. Orkin SH, Kazazian Jr HH, Antonarakis SE, Ostrer H, Goff SC, Sexton JP. Abnormal RNA processing due to the exon mutation of $\beta^{\mathrm{E}}$-globin gene. Nature. 1982; 300: 768-769.

7. HbVar: A Database of Human Hemoglobin Variants and Thalassemias [Internet]. 2000 June [Updated 2015 October; Cited 2015 December 3] http:// globin.bx.psu.edu/cgi-bin/hbvar/query_vars3 ?mode=output\&display_format=page \&i=277.

8. Huisman T H J, Carver M F H, Efremov G D.A Syllabus of Human Hemoglobin Variants (1996) [Internet]. 1996 [Cited 2015 December 3] http:// globin.bx.psu.edu/html/ huisman/variants/beta/ E.html 